\title{
A second wave of gentrification: The case of Parkhurst, Johannesburg, South Africa
}

\author{
Paul Tsietsi Monare \\ Nico Kotzé \\ Tracey Morton McKay
}

Paul Monare, University of Johannesburg, Department of Geography, Environmental Management and Energy Studies, South Africa (nicok@uj.ac.za)

Nico Kotze, University of Johannesburg, Department of Geography, Environmental Management and Energy Studies, South Africa (nicok@uj.ac.za)

Tracey Morton McKay, University of South Africa, Department of Environmental Sciences, South Africa (mckaytjm@unisa.ac.za)

\begin{abstract}
As in many other countries, gentrification and urban regeneration occurs across South Africa. Despite this, geographical research on gentrification in South Africa is limited. This study adds to the literature by presenting the case of Parkhurst, a Johannesburg surburb. The study found that Parkhurst displays numerous characteristics of gentrification. The housing stock has undergone extensive physical improvement, with almost one third renovated or under renovation. Property values have increased and the original residents have been displaced. Parkhurst has a demographic and a socio-economic profile typical of a gentrified suburb. It is populated by young, white, educated, weathy professionals people. In addition, gentrification has resulted in the conversion of residential into commercial space, with some residences converted into business premises. The result is a distinct linear commerical zone within the neigbourhood. Gentrification is also associated with a change in housing tenure from rentals to ownership, it was found that ownership was a common feature of Parkhurst. Overall, it was concluded that gentrification of the suburb has occurred over an extensive period of time and is now in a super-gentrification stage.
\end{abstract}

Keywords: gentrification, Parkhurst, Johannesburg, South Africa, urban renewal

\section{Introduction}

Although the definition of gentrification has become a contested concept over time, the original definition was coined by Ruth Glass in 1964 (Lees, 2008). That is, gentrification is associated with the residential displacement of working class people by middle class individuals who then use their financial resources to physical transform residential suburbs into upmarket accommodation, the consequence of which is rising property values (Hoogendoorn, 2006; Butler, 2007). In terms of the property investment cycle, disinvestment is often the first step in the process. That is, buildings fall into disrepair, values decline and municipal revenue from the area falls. Subsequently municipal-wide disinvestment from the area occurs, where municipal services - such as pavement cleaning and park maintenance become either intermittent or completely withdrawn. A downward spiral ensues, where rental returns become depressed. Landlords, under pressure to obtain sufficient return on investment, often subdivide to increase the number of tenants per unit so as to compensate for loss of revenue. The lower rentals usually attract only lower income people and the area becomes locked into a system that limits economic growth (Slater, 2004; Fyfe \& Kenny, 2005). Should such a 'run-down' area be located within an economically attractive zone, or is characterised by unique architecture and/or is home to restaurants, then gentrification, that is re-investment, could later occur. Once this happens, poorer or working-class residents are 
displaced by rising rentals (Kennedy \& Leonard, 2001). Thus, it is argued that gentrification is a varied form of urban regeneration and results in a class transformation of the neighbourhood owing to tenure and housing stock value changes (Bourne, 1993; Bridge \& Watson, 2000). Gentrification is, therefore, a process by which urban space is re-shaped to accommodate the demands of production and the desire for profit by builders, developers, landlords, mortgage lenders and real estate agents (Smith, 1996). Within the South African context, gentrification has been researched by a number of investugators, most of which focused on the City of Cape Town (see Garside, 1993; Kotzé, 1998; Kotzé \& Van der Merwe; 2000; Visser \& Kotzé, 2008, Kotzé, 2013). Other cities such as Bloemfontein and Johannesburg have been subjected to much more limited scrutiny (Rule, 2002; 2006; Hoogendoorn, 2006). Thus there is a gap in the literature concerning the process of gentrification in South Africa and Johannesburg in particular (Visser, 2002). This study, therefore, was undertaken to partly address this lack of academic reflection and takes on the following format: Firstly, the international trends in gentrification are outlined, followed by a more detailed description of gentrification patterns in South Africa. The study area and methodology is then described. Results, in terms of demographic and socio-economic profile, as well as analysis of the property renovations, is then given and a number of conclusions drawn.

\section{Gentrification Trends: An International Perspective}

Internationally, there are a number of examples of 'classic' gentrification (Lees et al., 2008). One of which is that of Barnsbury in London. Barnsbury underwent a serious decline after World War II when upper-income residents relocated to newly-built suburban houses on the outskirts of the London CBD. The suburbs became deserted and working-class people moved in as rentals were low. Sub-letting and large families meant that overcrowding began to characterise the area and soon physical deterioration, due to the inability of these households to adequately maintain their homes, set in. In the late 1950s building societies began to lend money to invest in old properties such as those in Barnsbury and so gentrification commenced. The result was the proportion of middle-class people living there started to increas (Lees et al., 2008). Another example of classic gentrification is that Park Slope, New York City. Park Slope experienced a significant loss of middle-class residents due to suburbanisation at the beginning of the $20^{\text {th }}$ century. The 1930s Depression years led to the physical decline of Park Slope until it was classified as a slum. Matters become worse in the 1940s to 1970s when 'white flight' occurred and white people left the New York inner city for the surroundings suburbs (Lees et al., 2008). A vicious circle ensued as the white population was replaced by black and Hispanic people, most of whom were low-income earners or unemployed, thus systematic disinvestment followed. Eventually the neighbourhood was trapped in a cycle of economic depression and physical decline (Carpenter \& Lees, 1995). Finally, in the 1970s, the government intervened, passing legislation to encourage reinvestment in the area. Property developers, neighbourhood organisations and pioneer gentrifiers (or sweat workers) moved in. The 'sweat workers' did much of the renovation work themselves, although they received loans to finance some of the renovation costs (Carpenter \& Lees, 1995). Contemporary gentrification is now taking place in many different locations across the world (Atkinson \& Bridge, 2005).

Unlike in the past, where this process was found mainly in English-speaking countries, it is now emerging in Eastern Europe, Asia and South America (Smith, 2002). Furthermore, gentrification has moved away from inner city suburbs to more peripheral ones, and even to rural areas (Badcock, 2001; Philips, 2004). The result of which led Phillips (2004) to call for geographers to focus on alternative gentrification geographies, such as the 'gentrification' of commercial development (Curran, 2004). It was also found that some suburban areas are 
undergoing a second form of re-investment and re-generation, which is dubbed 'supergentrification' or 'new-build gentrification' (Butler \& Lees, 2006; Lees, 2003; Rose, 2004). Clearly, gentrification has becoming more complex over time (Davidson \& Lees, 2005).

The gentrification process can be viewed in two main ways, the production-side focuses on the economics of the process, namely the relationship between inflows of capital into an urban space and the subsequent production of such a space. The second, consumption-side view, focuses on the characteristics of the gentrifiers and their consumption patterns and is located in broader spheres of urban culture and the post-industrial society debates (Ley, 1996; Visser, 2002). Gentrification can have both negative and positive consequences (Lees, 2000; Kennedy \& Leonard, 2001). There is, for example, much written in the popular press on how gentrification can lead to high levels of social mixing, which, in turn improves the quality of life. That said, a study of gentrification in the United Kingdom and Scotland did not find much evidence of gentrification induced social-mixing actually improving well-being (Doherty et al., 2009). In addition, original residents may suffer a 'loss' when a former 'well loved' and popular corner store is replaced by major chain pharmacy. But this pharmacy may offer residents greater retail choice and lower prices per item (Kennedy \& Leonard, 2001). However, often the negative consequences are not as benign as the loss of a corner store. They can include racial injustice, conficts between old and new residents, the loss of cheap rental accommodation or commerical space and increased property taxes (Atkinson, 2000; Kennedy \& Leonard, 2001; Powell \& Spencer, 2003). For many cities, gentrification is linked to public policy (Lees \& Ley, 2008; Lees et al, 2008). As has been noted, for gentrification to take place in London, government grants were essential (Hamnett, 1973). In addition, a core driver of gentrifiction are public policies that place gentrification at the heart of urban renewal (Cameron \& Coafee, 2005). Thus, "more than ever before, gentrification is incorporated into public policy either as a justification to obey market forces and private sector entrepeneurialism, or as a tool to direct market processes in the hopes of restructuring urban landscapes in a slightly more benevolent fashion" (Wyly \& Hammel, 2005: 35). As a consequence, it has been argued that gentrification is not a process that can be resisted, but rather one that needs to be managed (Freeman, 2006; Slater, 2006). They argue that if gentrification is embraced and well managed, it can be used to retain a more equitable and just society.

The international literature also notes that gay and lesbian households are often key 'pioneer' gentrifiers. In particular, it has been found that gay men play a significant role in urban inner-city re-development (Sibalis, 2004). That is, internationally, gay and lesbian households use their cultural and financial resources to create new meanings in the urban landscape. This redefinition of space is usually associated with a resexualation of space and it taking on a more cosmopolitan 'feel' (Bell \& Binnie, 2003; Smith \& Holt, 2005). Despite the paupicy of specific literature on gentrification and homosexuality, the relationship between space and sexuality has been explored by a number of scholars. Space plays a significant role in the expression of sexuality. In particular, gay and lesbian people actively create and seek out both public and residential spaces where their sexuality does not have to be hidden (Visser, 2003). Other scholars have focused on the way in which gay and lesbian spaces have been created and maintained (Valentine, 2002; Gorman-Murray \& Waitt, 2009). A prominent example is Castro, an inner city suburb of San Francisco in the USA. In Castro, gay men enthusiastically committed to the renovation of both the commercial and residential space of the area. However, although space plays a significant role in the expression of sexuality, the role of sexual orientation in gentrification and the construction of urban space are relatively unexplored in the literature (Visser, 2003). 


\section{Gentrification in the South African context}

South African cities in general face serious urban planning challenges such as decentralisation and suburbanisation. The consequences of which are major capital disinvestments from the inner city and 'white middle class flight' from suburbs that surroud the CBDs. Many CBDs are now faced with significant urban decay (McDonald, 2008). Thus, since the early 1990s, urban development strategies have been implemented in South Africa that track global urban regeneration trends. That is, urban planners, private developers and government bodies have been working on urban development policies to combat decentralisation (McDonald, 2008; Visser \& Kotzé, 2008). As property value decline it has undermined the ability of muncipalities to generate property tax income with many South African cities adopting gentrification as a form of urban regeneration (Visser \& Kotzé, 2008). Despite such trends, little geographical research has been conducted of late on genertrification of inner city suburbs in South Africa. In the past, most South African urban geographers focused on researching the development of the apartheid city, the urban economy, as well as black townships (McCarthy, 1992; Visser, 2013; Visser \& Rogerson, 2014). Recent literature though, is starting to reflect the role of gentrification in influenting the physical, economic and social characteristics of South African cities (Kotzé \& Van der Merwe, 2000; Visser \& Kotzé, 2008).

Gentrification emerged in South Africa in two distinct phases. The first phase occurred between the 1950s and 1980s. This first phase can be described as typical 'classic' gentrification with class displacement (Bond, 2000). Investigations by both Garside (1993) and Kotzé (1998) demonstrate that this first phase was consumption-driven, with middle-class residents renovating their dilapidated properties to increase their value, driving working class people out due to increased property values. For Garside (1993) this was linked to the racial desegregation of the city, with Coloured people displacing White residents in the suburb of Lower Woodstock. Such trends have continued throughout Cape Town and Johannesburg, as the cities have slowly, but steadily desegregated. Gentrification in South Africa has different racial implications compared to that of the United States of America (Garside, 1993; Visser, 2002). Unlike the United States of America, where the Black working class often fall victim to gentrification, Black, Coloured and Indian people in South Africa can be the agents of gentrification, owing to the rise of a Black middle class and the demand for housing. The result is the displacement of poor and working class White people. The second phase is linked to the emergence of a state sponsored 'urban renaissance' that coincided with the demise of apartheid post 1994 (Visser \& Kotzé, 2008). This second phase can be located in urban regeneration debates (Kotzé \& Van der Merwe, 2000). That is, local government came to view gentrification as a means to combat inner city decline. For the private sector, the incentive is clearly the "rent-gap", which opens up opportunities for good returns on property investment (see Smith, 1987). Thus, as opportunities for investment and re-development have accelerated in South Africa, gentrification continues apace (Visser \& Kotzé, 2008). The result is the rise of new Central City Improvement Districts (in Cape Town, Johannesburg and Pretoria' for example) and other large infrastructural investments in former CBDs, such as the re-development projects at the Victoria \& Albert Waterfront, the Foreshore (both in Cape Town) and the Blue IQ Projects in Johannesburg (Van Zyl, 2005; BlueIQ, 2014). There is also some evidence of a possible 'third' phase of gentrification taking place in South Africa with the rise of gentrification in peripheral 'black' townships, where residents are investing in their housing stock (Visser, 2002). Much more research is required on this new gentrification process, in particular, to determine if it is resulting in class displacement or not. Finally, Visser (2002) argues that there is an emerging trend of rural gentrification, where wealthy urbanites, usually white South Africans, are purchasing and renovating second homes in smaller rural towns. In most cases this is for retirement purposes or as a holiday home. 
Importantly, in terms of gentrification, it was found that some areas in Cape Town have experienced gentrification by developing as sites for gay leisure and tourism consumption (Visser, 2002; Elder, 2003). De Waterkant, a suburb of Cape Town, is one of the best examples of a gentrified and re-sexualised area. Between the years 1994 and 1999, close to three-quarters of all properties in the suburb had undergone some form of renovation. Most of this gentrification occurred because of wealthy white gay individuals purchasing the properties as second homes. When not owner occupied, the majority are let out as either serviced and/or self-catering accommodation for tourists, with almost all these tourists being gay (Visser, 2002). Thus, the property market in De Waterkant, has been positively affected by the movement of gay-tourism-generated capital (Visser, 2003). The suburb is favoured by wealthy international gay tourists due to the upmarket facilities and close proximity to Cape Town’s gay leisure spaces (Elder, 2003; Visser, 2002 \& 2003).

There are a number of key trends emerging in the South African gentrification and urban literature: Firstly, South Africa has experienced a significant change in the cycle of urban decline over the past decades (Visser, 2002). The decay of many of South Africa's inner cities however, provides opportunities for both the public and private sectors to address the urban regeneration and gentrification processes by creating living spaces in former commercial zones, such as the Central Business Districts of Johannesburg, Cape Town and Pretoria. Secondly, gentrification in South Africa is currently not taking on the American (USA) form of black-white displacement (Visser, 2002). Unlike the case in the United States of America, where the black working class often fall victim to gentrification, black, Coloured and Indian people in South Africa are also agents of gentrification, owing to the rise of a black middle class. A third theme in the South African gentrification literature is establishing where displaced working class and poor whites have re-located to. To date, these studies in postApartheid South Africa as is the case of most gentrification studies all over the world often fails to follow up or establish what happens to these displaced people (Visser, 2002). A fourth theme is that of investigating the rise of a Black middle class in the former Black townships. Although the townships are often portrayed as impoverished neighbourhoods occupied by struggling Black working-class residents, without a doubt some are showing the signs of accommodating an emerging black middle class (Visser, 2002). A fifth theme to emerge is that of academics questioning the desirability of gentrification, as it certainly has the potential to result in the destruction of South Africa's historical architectural legacy. In South Africa, restored historical sites are significant tourist attractions in Cape Town, Johannesburg, Durban and Pretoria, for example (Visser, 2002). Thus, there is a need to explore the cost benefit ratio of gentrification and urban renewal within a broader economic debate, a path some South African gentrification researchers are sure to tread. Lastly, there is an emerging theme concerning rural gentrification. Displacement becomes an issue once again and raises the question as to whether more impoverished rural towns can benefit from the new incoming migrants (Visser \& Kotzé, 2008).

\section{The study area}

The residential suburb of Parkhurst is about 162 hectares in size and situated northwest of the Johannesburg city centre (see Figure 1). Topographically, Parkhurst is sited on one of Johannesburg's steeper hills, with most of the neighbourhood boundaries demarcated by streams or watercourses. Adjacent to Parkhurst are the suburbs of Parktown North, Westcliff, Saxonwold, Emmarentia and Greenside. Originally forming part of an old farm, Braamfontein, Parkhurst was established in 1904. For much of the early years, land sales and housing development was slow, only intensifying as a result of the serious housing shortage that faced Johannesburg after the Second World War. It became a popular residential area for returning soldiers as houses were cheap (Truluck, 2004). Most of the houses are on small 
erven, ranging from $495 \mathrm{~m}^{2}$ to almost half a hectare (Rule, 2006). By the end of the 1950s Parkhurst was officially classified as a suburb and sported its own sewerage system, piped water, electricity, street trees, a junior school, tarred roads, shops, churches and sports fields.

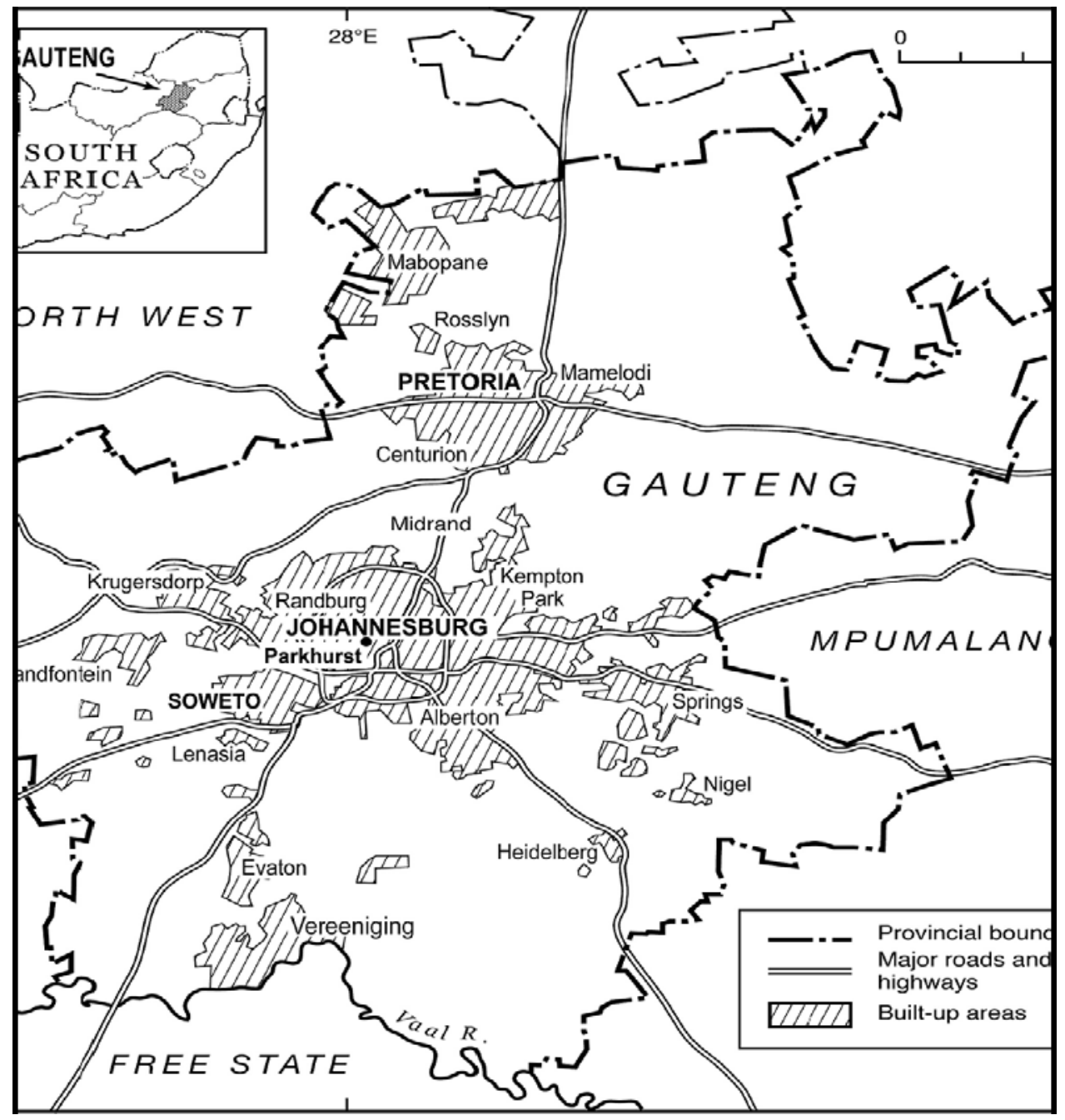

Figure 1: Parkhurst, Johannesburg, north of the CBD

By the 1960s, the suburb gained popularity (Truluck, 2004; Rule, 2006). Until the repeal of the 1950 Group Areas Act, Parkhurst was legally designated as a 'white space' and home to white residents only (Rule, 2006). Commercial development in Parkhurst was well established by the 1980s, along Fourth Avenue, with small corner cafés, clothing shops, butcheries and barbers, serving the local community. The scenario remained unchanged until the 1990s when commercial transformation commenced, with modern retail services being established. Over time, antique stores, upmarket restaurants and interior-design consultancies came to dominate the commercial space. Such retail outlets appeal to wealthy home buyers and many purchased homes in Parkhurst as a result (Rule, 2006). Adding to the popularity of the suburb is its close proximity to popular shopping and commercial nodes, such as Rosebank, Parktown North and Greenside (see Figure 2). 


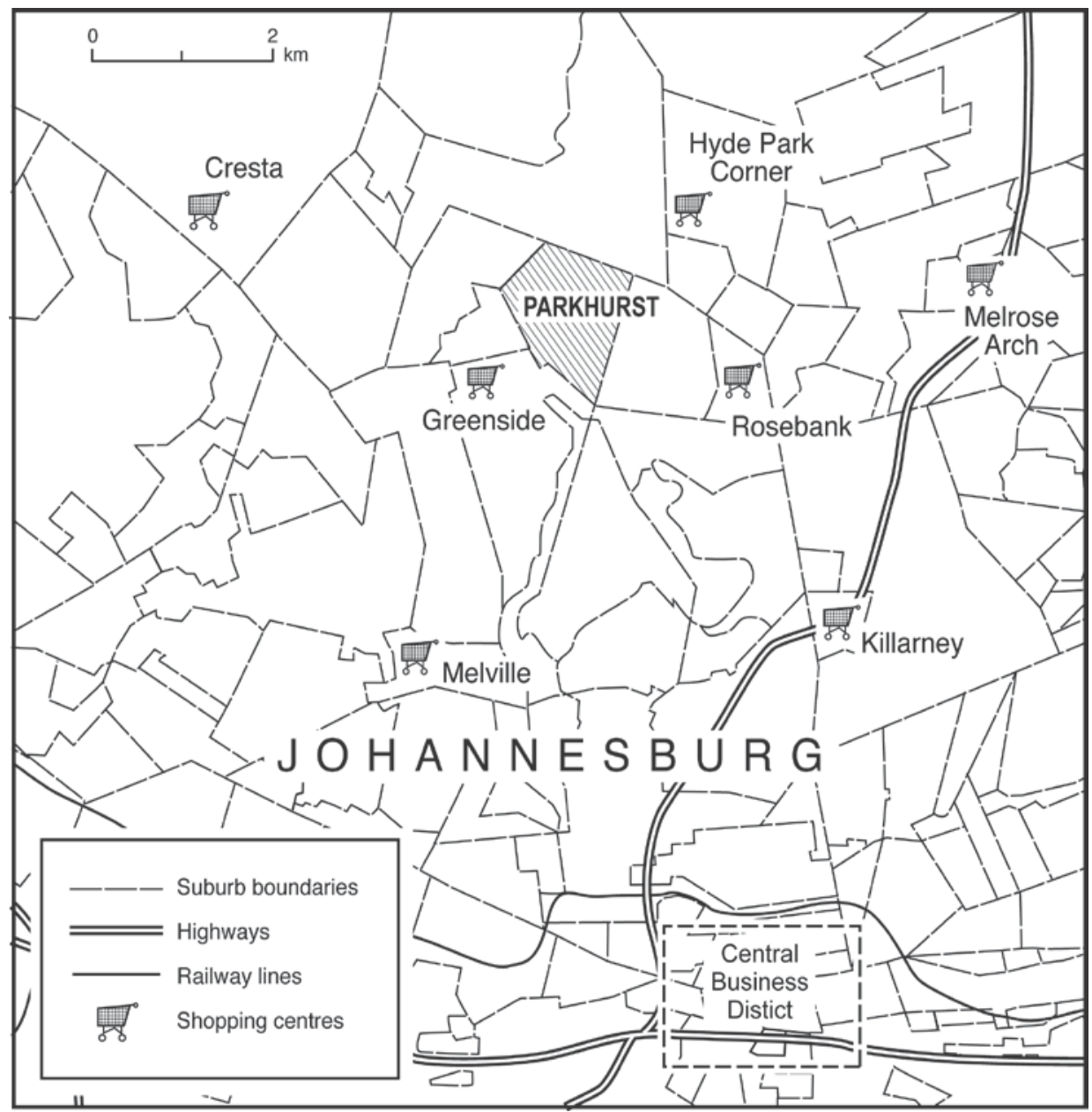

Figure 2: Positioning Parkhurst in relation to major shopping malls

\section{Methodology}

Mixed methods (qualitative and quantitative) were used for the purpose of this study. The focus was on qualitative methods to gain an in-depth understanding of gentrification in the suburb. The quantitative methods were used as a supplement to gaining empirical support for the research hypotheses (Holiday, 2007). This study had three research questions, namely: First, has the demographic profile of Parkhurst undergone a change? Secondly, has the original physical character (built environment) of Parkhurst changed? And finally, have the original residents been displaced? In order to determine the socio-economic and demographical profile of the residents, as well as to ascertain the level of investment into the housing stock, a self-administrative questionnaire was randomly distributed to various Parkhurst residences. Of the 200 questionnaires were distributed, 54.5\% were completed and returned. The questionnaire was based on a similar one used in other gentrification studies in South Africa (see Kotzé, 1998; Kotzé \& Van der Merwe, 2000). Data was verified by conducting semi-structure in-depth interviews with key stakeholders, such as tenants, homeowners, landlords, estate agent, the local councillor and business-owners in Parkhurst. All participants gave informed consent, anonymity was guaranteed and all could opt out of the study should they have wished to.

\section{Results and Discussion}

The study found that there has been a significant change within the suburb and its residents. Racially, there was minimal change, as the residents are still overwhelmingly white, but the study found that the gender and age profile of the suburb had changed significantly. 
Firstly, Parkhurst has a skewed gender ratio, with 54\% being male. This is in stark contrast to the rest of South Africa, where males constitute $48 \%$ of the population (Statistics South Africa, 2011). Not only does this skewed gender ratio differ from the rest of South Africa, it also differs from a decade ago, when males only constituted $44 \%$ of Parkhurst's population (Statistics South Africa, 2001). Thus, the suburb has seen a significant influx of men (10\% in ten years). Furthermore, a significant proportion of these males self reported that they lived in a male only household (only a few women self reported that they lived with other women). Secondly, in terms of age, unlike the findings of Statistics South Africa (2001), where the majority of residents were below the age of thirty, this study found that most of the residents are aged between the ages of 30 and 50. Thus the suburb has witnessed a decrease in the number of children and people over 50 and an influx of younger people. Internationally, the demographic characteristics of a typical gentrifier are: young, white and single (Badcock, 2001; Lees et al., 2008). Parkhurst residents fit this profile, except that marriage rates are higher. The difference in marriage rates could be attributed to generally higher marriage rates in South Africa compared to most developed nations.

Internationally, the characteristics of a typical gentrifier also include being educated, wealthy and enjoying elevated social status, such as working in the creative professions or white-collar occupations (Cameron, 1992; Kotzé, 1998; Badcock, 2001; Lees et al., 2008). In terms the socio-economic profile, Parkhurst also mirrors these international trends. The majority of Parkhurst residents are educated and have a much higher household income than the rest of South Africa, Johannesburg included (Statistics South Africa, 2011). The education levels for residents in Parkhurst have, for instance, improved significantly since 2001. The overwhelming majority of Parkhurst's residents now possess at least a university degree. This education profile is radically different from that of the rest of Johannesburg, where the majority of residents only have a high school qualification. Furthermore, many Parkhurst residents are white collar professionals and many of the households are dual income, a trend that mirrors that found by Nico Kotze (1998) for Cape Town.

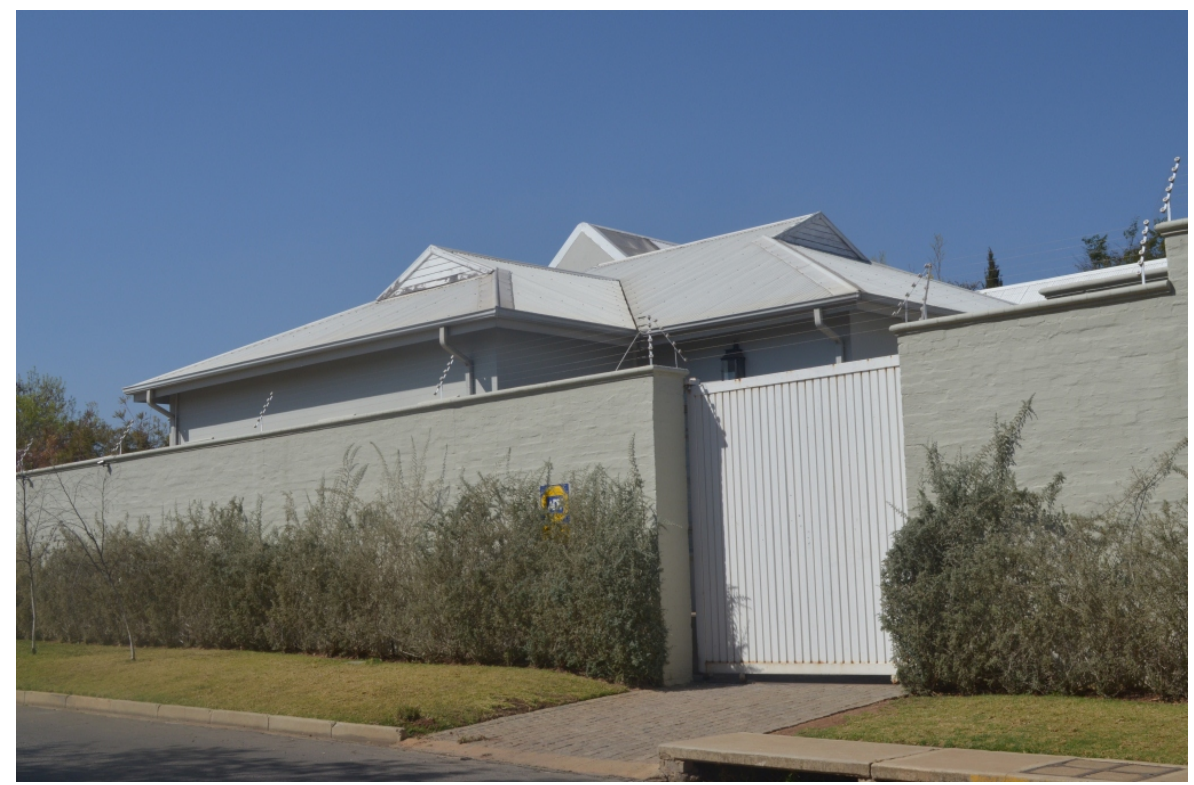

Figure 3: A typical Parkhurst residence, high perimeter walls, electrical fencing, and additional security. 


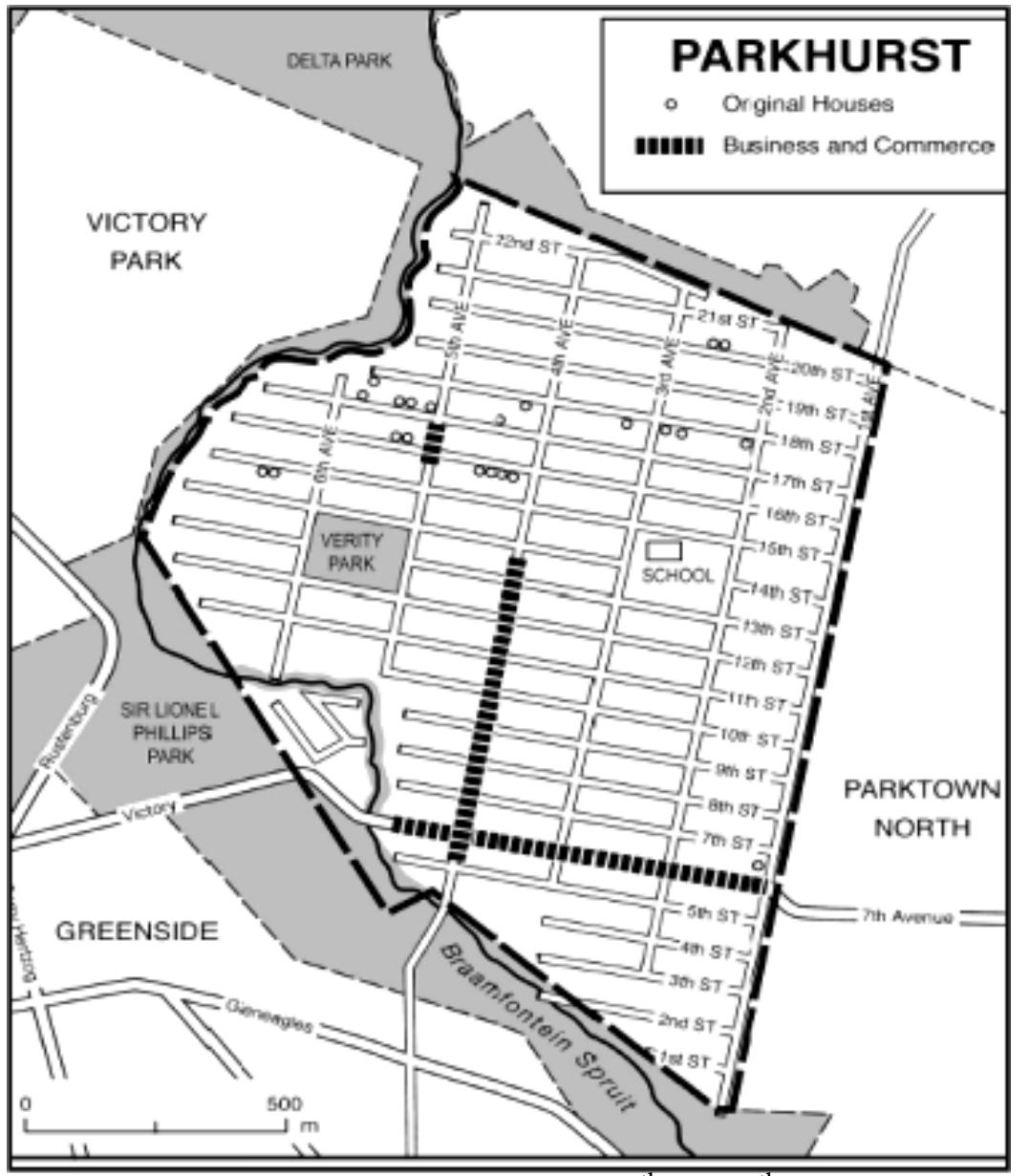

Figure 4: The commercial ribbon development along $4^{\text {th }}$ and $7^{\text {th }}$ Ave, Parkhurst, with the few houses unchanged shown.

In terms of the physical (housing) characteristics, the typical Parkhurst house is now a, low maintenance, middle-class home with a garden, car ports and a double garage (Rule, 2006). High perimeter walls, topped with electrical fencing and sometimes CCTV security equipment dominate (see Figure 3). Typical of many northern Johannesburg suburbs, access into certain portions of the suburb is limited due to road closures (Landman, 2002). Property prices reflect both increased investment in the homes, and considerable market demand (Rule, 2006). For example, in the late 1990s, the average price of a house on sale in Parkhurst was R355 000. Ten years later, the asking price for a renovated home was R600 000 (Rule, 2006). By 2012, the asking prices of houses (virtually all renovated) in Parkhurst ranged from a low of R1.8 million to a high of R3.3 million (Property24, 2012; Kings Real Estate, 2012; Geraldine Lewis Estates, 2012; Vered Estates, 2012; Sotheby’s, 2012; and Pam Golding Estates, 2012). More bedrooms and greater degree of renovation accounts for the 2012 price range.

Additionally, gentrified suburbs usually experience a conversion of residential properties to commercial properties. This is also the case for Parkhurst, with much commercial activity taking place along Fourth Avenue and Sixth Street (see Figure 4).

Along these two main 'commercial' streets, houses are being converted into offices, retail and restaurants and business being renovated and redeveloped, by adding additional floors to the units (Figure $5 \& 6$ ) at an increasing pace. To determine the spatial extent of the commercial development, the streets were measured. Along Fourth Ave, the total length of commercial conversions was found to be $822.5 \mathrm{~m}$, where $67.7 \%$ of the business conversions are for retail functions such as shops and supermarkets (e.g. "Hip-Hop”, "Christina Marina”, 
"Paul Smith”, "Parkhurst Paint”, “Urban Spaza” and "Polly Porter”) or bookstores. Restaurants (such as "Peroni”, "Georges on $4^{\text {th" }}$, and "Possum's Bistro and Deli") occupy $17.2 \%$ of the commercial space, with the majority of restaurants in Parkhurst being located along this street. Other streets would come under similar pressure, except that the residents and city council are vigorous in their monitoring of all conversion applications and systematically turn down those outside of the main commercial 'ribbon' streets. This is partly owing to the significant traffic congestion such conversions cause, as well as, noise pollution that emanates from the restaurants and pubs.

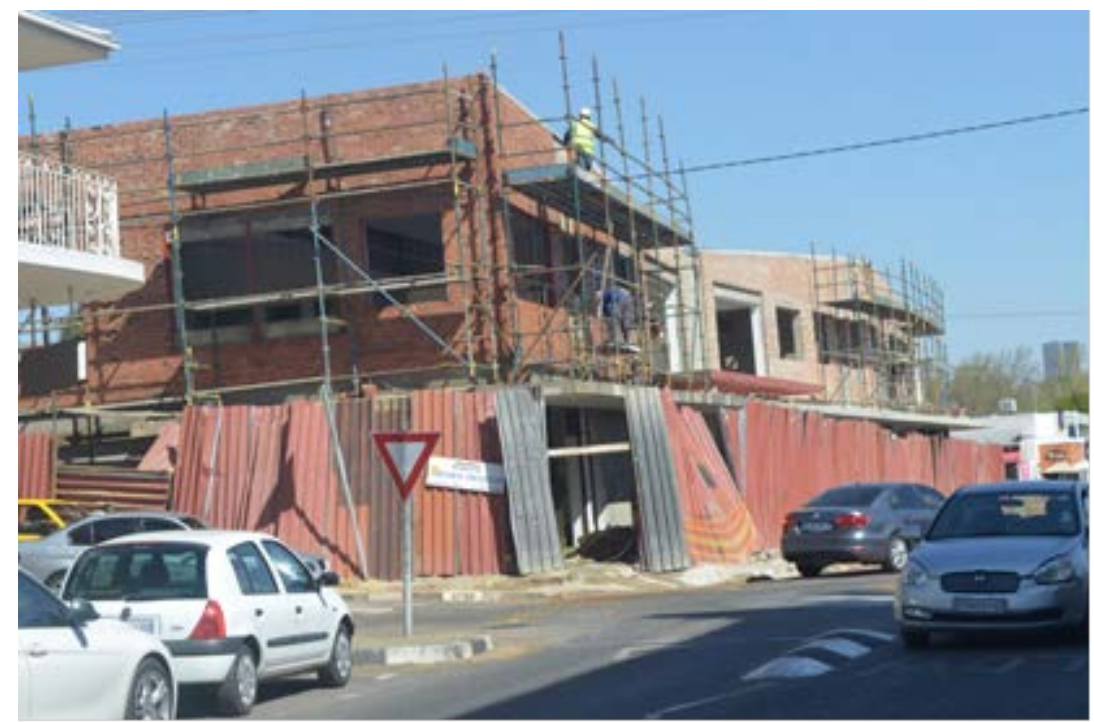

Figure 5: Business-unit renovation and redevelopment

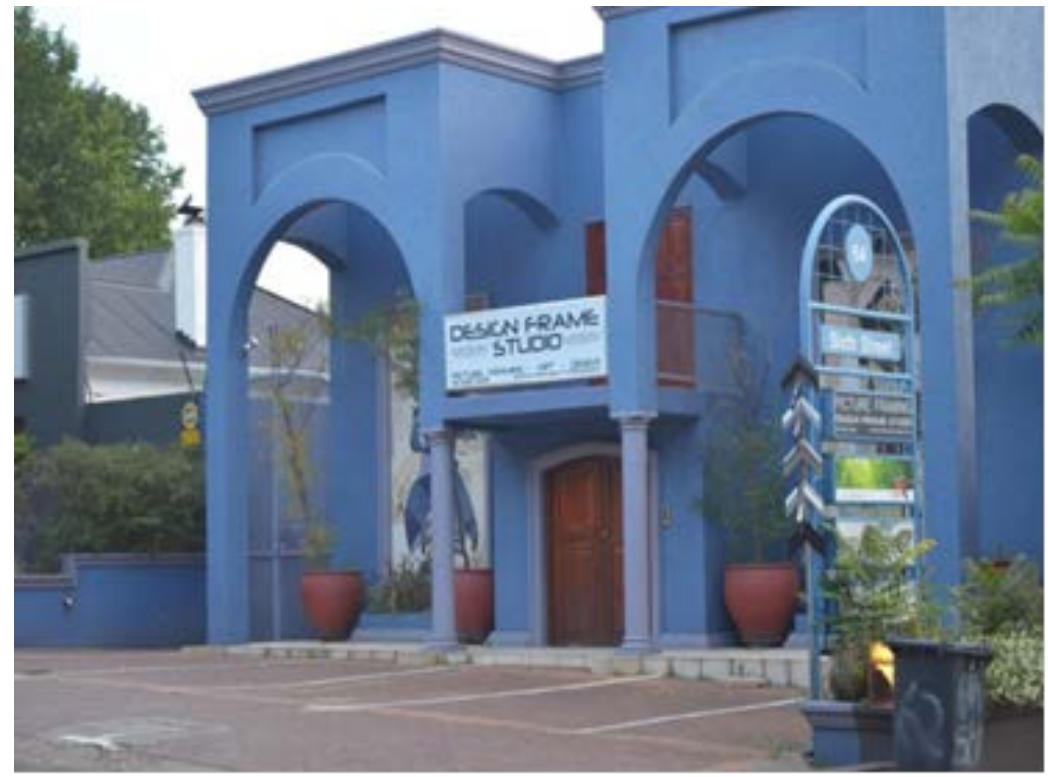

Figure 6: A typical home-to-office space conversion

Although there are some remarkable similarities between Parkhurst and international case studies of suburbs which have undergone gentrification, there are also some differences. In the process of its gentrification, the suburb of Parkhurst, like its international counterparts, lost its original residents - returning soldiers and working class residents. However, in the case of Parkhurst, this occurred in the 1970s and 1980s. Thus, Parkhurst has passed a peak of the first gentrification cycle and the suburb is now in the process of super-gentrification. 
Therefore, the typical displacement pattern found internationally, where upper-income residents replace lower-income residents is not occurring in Parkhurst at present. This notion of a 'second round' or super-gentrification process is also supported by the finding that most houses were already renovated prior to the newer residents moving in. The newer residents have embarked on additional renovations, further driving property values. This clustering of upmarket homes draws in upmarket residents and the subsequent pool of consumer demand created by such densities of wealth places pressure on the land use zoning of the suburb. In particular, despite zoning by-laws and vigilance by the local councillor, commercial property market pressures on Fourth Ave, for example, see the continued conversion of residential property into valuable office and retail space. The proximity of Parkhurst to major shopping centres and the rise of the Gautrain Rosebank station will continue to re-shape property values and development into the future.

\section{Conclusion}

This study found that in the South African context, gentrification, while involving neighbourhood change, does not necessarily involve residential succession and the displacement of the original working class residents. However, this study found that although the demographic profile of Parkhurst has changed significantly through the years, to that of wealthier residents, the overall class nature and the housing stock of the suburb has moved even moved further upmarket. That is, it is still home to some middle class residents, but increasing number of upper income white people is calling it home. These changes and upgrading of residential and urban space may represent super-gentrification cycle (displacement of middle class individuals with the urban elite). Recent restoration and renovation has significantly changed the physical features of the houses, helping to drive increased property values and encourage the influx of businesses servicing an upper class or elite clientele. As such, gentrification in Parkhurst may represent the demands of the South African elite for the production of 'elite urban space' and a house is not only a home or shelter, but also an investment vehicle. Interesting is the gendered nature of this process, where more white males have made Parkhurst their 'home'. To this end, this study is also positioned within South Africa's emerging economy and reflects the extent to which Johannesburg is rapidly transforming to mirror global trends in gentrification.

\section{Acknowledgements}

The authors would like to thank Wendy Job of the UJ Cartographic Unit for the maps, Tim Trulock for assistance in data collection, the residents and business owners of Parkhurst for their extensive co-operation. Errors and omissions are our own. All photographs are the authors' own.

\section{References}

Atkinson, R. (2000) Measuring gentrification and displacement in Greater London. Urban Studies, (37), pp.149-166.

Atkinson, R, \& Bridge, G. (eds.) (2005) Gentrification in a global context: the new urban colonialism, London: Routledge, pp. 18-38.

Badcock, B. (2001) Thirty years on: Gentrification and class changeover in Adelaide's inner suburbs, 1966-96. Urban Studies, (38), pp. 1559-1572.

Bell, D. \& Binnie, J. (2004) Authenticating queer space: citizenship, urbanism and governance. Urban Studies, 41(9), pp. 1807-1820.

BlueIQ (2014) Joburg, my city, our future. http://joburg.org.za [Accessed on 22 August 2014]. 
Bond, P. (2000) Elite transition: from apartheid to neo-liberalism in South Africa. London: Pluto Press.

Bourne, L.S. (1993) The demise of gentrification? A commentary and prospective view. Urban Geography 14(1), pp. 95-107.

Bridge, G, \& Watson, S. (2000) A Companion to the City. USA: Blackwell Publishing.

Butler, T. \& Lees, L. (2006) Super-gentrification in Barnsbury, London: globalization and gentrifying global elites at the neighbourhood level. Transactions of the Institute of British Geographer, 31(4), pp. 467-487.

Butler, T. (2007) For gentrification? Environment and Planning A, (39), pp. 162-181.

Cameron,R. (1992) Managing the Coloured and Indian areas. In Swilling, M. Humphries, R. \& Shubane, K. (eds.) Apartheid City in Transition. Cape Town, Oxford University Press. pp 48-61.

Cameron, S, \& Coafee, J. (2005) Art, gentrification and regeneration: from artist to pioneer to public arts. European Journal of Housing Policy, 5(1), pp. 39-58.

Carpenter, J. \& Lees, L. (1995) Gentrification in New York, London and Paris: An international comparison. International Journal of Urban and Regional Research, 19(2), pp. 286-303.

Curran, W. (2004) Gentrification and the nature of work: Exploring the links in Williamsburg, Brooklyn. Environment and Planning A, 36(7), pp 1243-1258.

Davidson, M. \& Lees, L. (2005) New build gentrification and London riverside renaissance. Environment and Planning A, (37), pp. 1165-1190.

Doherty, J., Manley, D. \& Graham, E. (2009) Is mixed tenure good for social well-being? Urban Studies, 46 (1), pp. 1139-165.

Elder, G. (2003) Malevolent geographies: sex, race and the apartheid legacy. Athens, Ohio University Press.

Freeman, L. (2006) There goes the hood: views of gentrification from the ground up. Philadelphia, Temple University Press.

Fyfe, N.R, \& Kenny, J.T. (2005) The Urban Geography Reader. New York, Routledge.

Garside, J. (1993) Inner city gentrification in South Africa: the case of Woodstock, Cape Town. GeoJournal, 30, pp. 2-35.

Gevisser, M \& Cameron, E. (eds.) (1994) Defiant Desire. Johannesburg, Ravan Press.

Gorman-Murray, A. \& Waitt, G. (2009) Queer-friendly neighbourhoods: interrogating social cohesion across sexual difference in two Australian neighbourhoods. Environment an Planning A, 41, pp. 2855-2873.

Hamnett, C. (1973) Improvement grants as an indicator of gentrification in Inner London. Area, 5(4), pp 252-261.

Holiday, A.R. (2007) Doing and Writing Qualitative Research, $2^{\text {nd }}$ Edition. London: Sage.

Hoogendoorn, G. (2006) Critical Perspectives on the (Re)Development of Westdene, Bloemfontein. Unpublished Masters Dissertation, Bloemfontein, University of Free State.

IOL, (2012) Online Property Guide. http://www.iolproperty.co.za/search_print.php?fPublicationId=7\&wl=true [Accessed 2 December 2012]

Kennedy, M. \& Leonard, P. (2001) Dealing with Neighborhood Change: A Premier on Gentrification and Policy Choices. The Brookings Institution Center on Urban and Metropolitan Policy. http://www.brookings.edu/research/reports /2001/04/metropolitanpolicy [Accessed 10 April 2014].

Kotzé, N.J. (1998) Gentrifikasie as stedelike-geografiese verskynsel in Kaapstad [Gentrification as an urban geographical phenomenon]. Unpublished Doctoral thesis, Stellenbosch,University of Stellenbosch. 
Kotzé, N.J \& Van der Merwe, I.J. (2000) Neighbourhood Renewal in Cape Town’s Inner City: Is it Gentrification? Journal of Family Ecology and Consumer Sciences, 28, pp. 3946.

Kotzé, N. (2013) A community in trouble? The impact of gentrification on the Bo-Kaap, Cape Town. Urbani Izziv, 24(2), 124-132.

Landman, K. (2002) Transforming urban spaces in South Africa: The impact of enclosed neighbourhoods on the urban future. In Donaldson, R. \& Marais, L. (eds.) Transforming Rural and Urban Spaces in South Africa During the 1990's: Reform, Restitution, Restructuring, Pretoria, Africa Institute of South Africa, pp. 381-406.

Lees, L. (2000) A reappraisal of gentrification: towards a geography of gentrification. Progress in Human Geography, 24(3), pp. 389-408.

Lees, L. (2003) Visions of urban renaissance. The Urban Task Force report and the Urban White Paper. In Imrie, R. \& Raco, M. (eds.) Urban Renaissance? New Labour, Community and Urban Policy, Bristol: Policy Press, pp. 61-82

Lees, L. (2008) Gentrification and social mixing: Towards an inclusive urban renaissance? Urban Studies, 45(12), pp. 2449-2470.

Lees, L. \& Ley, D. (2008) Introduction to a special issue on gentrification and public policy. Urban Studies, 45(12), pp. 2379-2384.

Lees, L., Slater, T. \& Wyly, E. (2008) Gentrification. New York, Routledge.

Ley, D. (1996) The New Middle Class and the Remaking of the Central City. Oxford, Oxford University Press.

McCarthy, J. (1992) Urban geography and socio-political change: retrospect and prospect. In

Rogerson, C.M. \& McCarthy, J.J. (eds.) Geography in a changing South Africa: Progress and Prospects, Cape Town, Oxford University Press, pp. 139-155

McDonald, D.A. (2008) World city syndrome: neoliberalism and inequality in Cape Town. New York: Routledge.

Phillips, M. (2004) Other geographies of gentrification. Progress in Human Geography, 28 (1), pp. 5-30.

Powell, J. \& Spencer, M. (2003) Giving them the old one-two: Gentrification and the K O of impoverished urban dwellers of color. Howard Law Journal 46(3), pp. 433-490.

Property24 (2012) Property Index. http://www.property24.com/property-values/12-2ndstreet/parkhurst/johannesburg/gauteng/c7ae2s66q47qotkbjrnj4w2tl54iba7vhtwq2zqvswa xoutw5ofa [Accessed 3 December 2012].

Rose, D. (2004) Discourses and experiences of social mix in gentrifying neighbourhoods: a Montreal case study. Canadian Journal of Urban Research, 13(2), pp. 278-316.

Rule, S. (2002) Post-Apartheid Parkhurst: Gentrification and Deracialisation. Transforming Rural and Urban Spaces in South Africa during the 1990s. Reform, Restitution, Restructuring, 10, pp. 225-248.

Rule, S. (2006) Suburban Transformation in Johannesburg. Kieler Geographische Schriften, 111, pp. 553-568.

Statistics South Africa (2001) 2001 census. Pretoria.

Statistics South Africa (2011) 2011 census. Pretoria.

Saturday Star, (2012) Property Guide, 14 July 2012.

Sibalis, M. (2004) Urban space and homosexuality: the example of the Marais, Paris's gay ghetto. Urban Studies, 41(9), pp. 1739-1758.

Slater, T. (2004) North American gentrification? Revanchist and emancipatory perspectives explored. Environment and Planning A, 36(7), pp. 1191-1213. DOI: 10.1068/a368

Slater, T. (2006) The eviction of critical perspectives from gentrification research. International Journal of Urban and Regional Research, 30 (4), pp. 737-757. 
Smith, D.P. \& Holt, L. (2005) Lesbian migrants in the gentrified valley and other geographies of rural gentrification. Journal of Rural Studies, 21, pp. 313-322.

Smith, N. (1987) Gentrification and the rent-gap. Annals of the Association of American Geographers, 77(3), 462-465.

Smith, N. (1996) The New Urban Frontier: Gentrification and the Revanchist City. New York, Routledge.

Smith, N. (2002) New Globalisation, new urbanism: gentrification as a global urban strategy. Antipode, 34, pp. 428-450.

Truluck, T. (2004) Parkhurst, First in a series on this Johannesburg Suburb. http://www.joburg.org.za/content/view/918/ (Retrieved 29 August 2009).

Valentine, G. (2002) Queer bodies and the production of space. In Richardson, D. \& Seidman, S. (eds.) Handbook of Lesbian and Gay Studies. Sage, London, pp. 145-160.

Van Zyl, P.S. (2005). The story of the Victoria and Alfred Waterfront Development. http://www.8linkd.com/sites [Accessed 21 August 2014].

Visser, G. (2002) Gentrification and South African Cities: towards a research agenda. Cities, 19, pp. 419-423.

Visser, G. (2003) Gentrification: prospects for urban South African society? Acta Academica Supplementum, 1, pp. 79-104.

Visser, G. \& Kotzé, N. (2008) The State and New-build Gentrification in Central Cape Town, South Africa. Urban Studies, 45(12), pp. 2565-2593.

Visser, G. (2013) Looking beyond the urban poor in South Africa: the new terra incognita for urban geography. Canadian Journal of African Studies, 47(1), pp. 75-93.

Visser, G. \& Rogerson, C. M. (2014) Reflections on 25 years of Urban Form. Urban Form, 25, pp. 1-11.

Wyly, E. \& Hammel, D. (2004) Gentrification, segregation, and discrimination in the American urban system. Environment and Planning A, 36, pp. 1215-1241. 